\title{
POLITICS OF JOKING: ETHNIC JOKES AND THEIR TARGETS IN ESTONIA (1890s-2007)
}

\author{
Liisi Laineste
}

\begin{abstract}
The article will describe the transformation of cultural heritage, focusing on ethnic jokes. Starting with the jokes from the 1890 s, which were collected by Estonian folklorist Matthias Johann Eisen (1857-1934) during the country-wide folklore collection campaigns tied to the idea of national revival and ending with the most recent jokes shared on the Internet, the article will give an overview of how a political system interacts with the universal rules of target choice (as described in Davies 1990, 2002 and elsewhere) in Estonian ethnic jokes. The analysis is cast into three subsections: First, it will give a brief overview of the old folk jokes that do not correspond to contemporary requirements for a joke that will "work", secondly, the similarity of joke tales and contemporary jokes from the 1960s until present day is examined, and finally the new and re-discovered old targets are analysed. The article will also consider the structural change of the genre, pointing at the universal stupidity joke cycle (for example, light-bulb jokes based on ethnicity) as the most suitable in the current globalising world and media.
\end{abstract}

Key words: ethnic humour, folk joke, jokes and social reality, joke tale, Soviet joke lore

\section{INTRODUCTION}

Ethnic jokes are usually specific to a certain society. They are dependent on a particular social, economic and cultural context. The choice of targets, the direction and even the content of mockery stems from the complex interaction of these factors, which operate not in a vacuum but in an environment that is unique in terms of both past developments and the present situation. But it is sometimes the political aspect of the societal context that plays a more influential role, visible in the way that politics downplays the social, economic and cultural context in the case of an oppressive political system. Jokes will then become politically motivated and tend to reflect the criticism towards the imposed hierarchy rather than growing out from the long-standing traditions in interethnic relations. A political system may thus influence the creation and 
content of ethnic jokes, offering new targets whose choice is explained by political rather than other motives.

The article will describe the transformation of cultural heritage, focusing on ethnic jokes. Starting with the jokes from the 1890s, collected by Matthias Johann Eisen ${ }^{1}$ during country-wide folklore collection campaigns in Estonia connected to the national revival and ending with the most recent jokes shared on the Internet, the article will give an overview of how a political system interacts with the universal rules of target choice in Estonian ethnic jokes. Telling changes have taken place both during the Soviet regime after the $1950 \mathrm{~s}$, but also after Estonia regained independence in 1991. Not intending to describe the continuity or origin of texts, I will analyse ethnic jokes which were spread in the 1890s and are in one form or another still part of our jokelore, and compare these with some texts that are specific to one certain era, circulating only then or now. The analysis will throw light on the tensions between the local and the global inside a tradition, showing the change in the direction of mockery from local numskulls to foreign targets (e.g., immigrant/neighbouring/Estonian groups versus ethnic groups or nations from the rest of the world). To be more specific, I will focus solely on ethnic jokes on stupidity (see general overview of Estonian jokes in Krikmann 1999, 2006, Laineste 2005, 2008). In addition to changes in the content and targets in ethnic jokes, there are great differences between the more formal aspects of the genre (length, style and language, punch-line) that will also be addressed in this article. These transformations are attributed to the need to create and consume (both listen and read) texts more quickly, as was argued also by Dorst (1990).

While describing jokes and their targets, I will refer to a theory of ethnic humour proposed by Christie Davies (1990, 2002 and elsewhere). To put it briefly, the theory proposes a set of universal rules for the choice of ethnic targets in stupidity jokes. For example, the stupid characters usually come from a society which is culturally close to the joke-teller and/or share a similar language, and are regarded as backward and employed in low-status manual work. Besides that, the joking relationship between joke-tellers and targets is characterised by asymmetry. Jokes are told in one direction only (for example, French about the Belgians, people from the Unites States about the Polish, English, Scottish and Welsh about the Irish, Canadians about the Newfoundlanders etc. For more examples see Davies 1990: 11). The present article attempts to complement this theory and account for the numerous cases that discard the rules in the Estonian ethnic jokelore: in the case of Estonia and presumably also many other post-socialist countries, jokes are told from the periphery to the centre (Estonian jokes about the Russians ${ }^{2}$ ), or even periphery to periphery (Estonian jokes about the Chukchis), there may be no linguis- 
tic similarities between the groups telling jokes about each other (Estonians about Latvians and Latvians about Estonians) or even any cultural or economic ties (Estonians about Blacks), neither are the nations involved in a joking relationship geographically approximate (Estonians about Americans). I will suggest that the presence of political pressure has in this case muddled up the emic target choices (that can be encountered, for example, in the earlier material collected by Eisen) and that this idea could help to explain the choice of targets in ethnic jokes in several other East-European countries as well. There are, of course, other factors interrupting the universals (such as globalisation in the form of strong cultural influence, or the general openness to loans and influences), but it is primarily the political aspect that will be under scrutiny in the following chapters.

\section{SOURCES AND METHOD}

The results are based on analysing the database of Estonian jokes (approximately 50,000 jokes, of which 4,000 are ethnic) covering the periods 1880 1910, 1950-1990 and 1991-2007. Each period is represented by an uneven number of jokes ( $c a 1,500$, ca 4,000 and $c a 42,000$, respectively). Relative proportions are used in the analysis. After removal of the replicas from the latest, most numerous portion of the dataset, around 19,000 different plots remained ( ca 50 per cent). The two earlier sets of jokes are mostly written down from personal conversations, and have been collected by local correspondents who sent these to Eisen for publishing, or by Estonian folklorists and linguists (e.g., Jüri Viikberg, Arvo and Luule Krikmann). Contemporary jokes (circulating after 1991) are copied from different home pages, joke collections and portals on the Internet and have been presented in the form of an Estonian-language online joke archive Eesti kaasaegsed anekdoodid (Online Joke Archive). All sets are characteristic of their time, representing the general tendencies in the choice of joke targets and other features of jokes of the period.

I will compare ethnic jokes from the three periods to describe their most important features, and point at the societal influences on the transformation that the jokes have undergone. The analysis will show that in addition to the asserted effect of close cultural and economic contexts, the political environment plays an important role in target choice. The development of the short and punch-lined format as a result of commodification of the old folk joke will support the line of argument presented in Wickberg 1998 (see also Kuipers 2002 on the influence of the Internet on jokes). Even though scholars have formulated quite different perceptions about the origin and age of the punch- 
line (for an intriguing discussion see Krikmann 2008), the fact is that jokes started to be shorter and more concentrated after the turn of the 20th century.

In this article, I use the notions of '(old) joke tale' and '(old) folk joke' as synonyms, and the term 'contemporary punch-lined joke' as its modern counterpart. Jokelore/joke tradition is an overarching term signifying the whole set of jokes circulating throughout the periods.

\section{ANALYSIS AND RESULTS}

In the next chapters, jokes from the three periods (pre-1910, 1950s-1990, and 1991-2007) will be analysed in order to find similar joke scripts of stupidity and their targets in order to see how political turns have affected the choice of targets in Estonian jokelore. Similar patterns should also be applicable to other post-socialist and post-colonial societies, where the oppressive power has interfered with the "emic" choices of ethnic target positioning (from the local, neighbouring, and culturally similar to faraway, culturally unrelated), and also mixing the ethnic and the political into one single undistinguishable ethnicpolitical or political-ethnic joke category. Examples of joke scripts that have disappeared or survived highlight the specific features and interests of the jokelore of each period.

Collections of old folk jokes, edited by Eisen and collected by his contributors, were published in several volumes (1895-1910), each consisting of about 200 unique texts. In his foreword to Eesti Rahvanali ('Estonian Folk Joke', Eisen 1909), Eisen also claimed that jokes (even if they have escaped the attention of collectors because they were too light-weight or frivolous) need to be documented and stored in archives for future generations. He admitted that next to the productive tradition of tragic or pragmatic folklore there had always been a thin but viable line of humour present in Estonian folklore. Tales of Kaval-Ants (Sly Hans) and Vanapagan (Old Devil) (ATU 1000-1199) often include incidences in which the trickster character Kaval-Ants outplays his strong and mighty but stupid opponent, tempting the audience to laugh at the latter. ${ }^{3}$ Eisen also criticised the translated jokes that started to appear in the Estonian daily Postimees in 1857 as not authentic and "Estonian" enough. The turn of the century was characterised by a heightened interest in "genuine" folklore, and Eisen positions the beginning of the Estonian joke tradition in the 1880s, when the newspaper Virulane started to publish traditional Estonian ethnic jokes on Hiiu men (men living on the island of Hiiumaa, Northwest Estonia). He was biased in collecting jokelore, and referred to his prefer- 
ences in the foreword of Eesti Rahvanali, stating that jokes must not be too obscene or profane/ungodly. Ethnic jokes escape both of these restrictions and it may be because of this that ethnic jokes are the most numerous category in his collections. ${ }^{4}$ His collections present a perfect material for researching the transition from old, long format folk jokes to short and punch-lined jokes, as both formats are present there. This is also evident in the fact that when going through the ATU index of old folk tales, the index is not applicable to categorise modern jokes. Most long and non-punchlined comic tales have disappeared or changed in terms of form. Also the content is at best similar, but not identical to contemporary jokes (see below for comparison examples of old and new jokes). Under the subcategory of stupidity (AT 1675-1724), or a special section of fabricated joke tales from Kilplased (AT 1200-1349), ethnic jokes are the most numerous. The stories of Kilplased were translated in the 19th century, and during the translating process, the stupid group itself got relocated: instead of being the Schildbürger from the 16th-century Germany, they became Kilplased from Uppakallo (a fictitious Estonian village). At the same time, many of the same plots were already known in jokelore and publishing the translated jokes about Kilplased was largely an example of fabricated lore, even though its target later became synonymous with general stupidity. Translating the targets (even if imaginary) along with the texts was perceived necessary, and as already noted, Eisen was critical of the translated jokes that retained a foreign target. As we will see later, the tendency to adjust the jokes to "local needs" disappeared since the Soviet occupation in Estonia (1940-1991). After the 1950s, not only were the targets left unchanged and adopted from Soviet jokes, the punch-line or the whole joke text was sometimes retained in, especially if it was based on puns, in Russian. The trend to prefer local ethnic characters in stupidity jokes has been re-introduced after the 1990s with Hiiu men and others from the periphery (in rare cases also Kilplased) as new targets.

\section{Targets of ethnic jokes}

Revisiting the idea that many old comic folk tales featured in Eisen's collection have become extinct by now, as they are too long or their topics out-dated, some examples that cannot be transferred to the contemporary society, and also those that still circulate with slight modifications will be considered. Their choice of targets will be analysed in order to see if the targets may also become outdated, and to observe the directions of change. 


\section{The impossible jokes: some old joke tales}

First of all, there is the most numerous set of old joke tales that have no equivalents in modern jokelore. Some joke tales were too long and complex to be remembered or retold. Although Eisen has collected many shorter jokes with a clear unexpected twist at the end, there are also instances where the punch-line is explained in a way that dismisses funniness, or where the joke stops even before the punch-line. An explicit moral at the end of the story does not qualify as a characteristic of a comic tale (for more differences, see Oring 1992: 81-82). An example of this is a joke that could be filed under contemporary black/absurd humour, only that the solution seems not particularly funny but expected, and is thus not incongruous enough. It is already short and certainly easy to understand, but the dialogue is logical and the absurdity of the humour does not outweigh the tragic presentation of the situation:

"How's your deceased child?" a woman living on the coast asks from another woman. - "Dead!" - "Did you cry when he died?" - "Sure I did! If you wish, I could do it even right now." (Eisen 1895/2002 No. 57: Kas surnud laps elab veel? [Is your deceased child still alive?] J. Ploompuu, Kuusalu parish, North Estonia.)

Also jokes on scarcity are missing, at least in the form they were told a century ago. In the case of old folk jokes on poverty, the daily struggle for bread is something characteristic of agrarian life, and cannot be avoided, much like the forces of nature. There is no irony or sarcasm in these jokes (unlike the Soviet jokes about the deficiency of elementary goods, which were essentially political). Only in a joke would a simple man know what fine bread with fish tastes like, or make a loaf of bread run after him for a while:

A Saare man [a man from the island of Saaremaa] bought a loaf of bread. He tied a string to the bread and pulled it along, saying, "Now you run after me, I am tired of running after you!" (Eisen 1896/2002b No. 49: Leib nööri otsas. [Bread on a string.] H. Reisar, Halliste parish, Southwest Estonia.)

Many of the forgotten jokes are short and incongruous, but have still been neglected as outdated because they depict issues that are irrelevant in a modern society. We see incompetence in how to handle animals correctly, what to eat and what not, what knowledge of the world is essential, or how to behave at public events, etc. Escaping wild beasts, such as wolves, is an issue often encountered in old folk jokes, as is the even more frequent theme of treating domestic animals: 
It so happened that a Hiiu man had to cross the bay in winter. Almost at home, his horse fell in an ice split. He had to run for help, but could not leave the horse in case it would die while he's gone. Finally, he came upon a good idea: he tied the horse's throat with a rope so that its spirit would not escape. The Hiiu man reached the nearest farmhouse. People were inside, sitting by the table and eating. The man joined them. After eating and drinking, the local peasant asked him, "What brings you here?" - "My horse, the old devil, fell into an ice split, I came to ask for help!" Everybody was boggled, "Why didn't you say so before?" - "I'm sure the horse is fine, I tied its throat properly," the Hiiu man replied. They went to the horse, but it had already kicked the bucket. The Hiiu man lamented, "Blast it! What an ass I am! Forgot to tie its backside! That's the hole from where the spirit finally escaped!" (Eisen 1895/2002 No. 14: Kinni siotud hing. [Tied spirit.] Anon.) AT 1293**; ATU Ø.

Mastering modern technological equipment is also a frequent theme inpresentday stupidity jokes, the classical examples being jokes about computers, domestic appliances, and the light-bulb joke cycle. In old folk jokes, this "technological stupidity" has different implications. Managing a successful farm house in a rustic small village was an esteemed skill, and screwing in a light bulb was not yet an issue for obvious reasons. A very vivid example is the following joke in which the stupidity of an islander is characterised by his limited understanding of the world and narrow horizons. This is, in a way, also a generalisation of the 19th-century society model - only these nations and locations were relevant with whom there was personal contact, which is not a very probable issue in the modern society:

A Kihnu man visited the mainland for the first time to sell his fish on the Pärnu market. He told himself, "The world is wide and large! There are people and villages beyond Pärnu. This means that the edge of the world is somewhere even further away!" (Eisen 1896/2002a No. 61: Maailma ots. [World's edge.] Eisen, Vigala parish, West Estonia.)

Or consider the following joke on heuristic/practical versus theoretical knowledge:

Two Hiiu men are on the mainland with their fish cart, on their way to the market. It's midnight. One man asks from the other, "How come the Moon is here? We left it behind when we left home." The other one answers, "Are you stupid or what? That's not the only Moon there is. There are heaps of them up there!" (Eisen 1896/2002a No. 30: Neid on nagu sääska. [There are heaps of them.] J. Ekemann, Tapa town, North Estonia.) AT 1334, ATU 1334A. 
These jokes explain the stereotypes about stupidity back then: the false beliefs and narrow understanding of the world were the main issues, and stupidity jokes could no longer follow the same scenarios, mocking backward beliefs (about the solar system, Earth and its inhabitants, medical knowledge, etc.) that seem too absurd nowadays.

\section{Old and new, local and global jokes compared}

The changes involve both the form and the content of jokes. There are also jokes that are recognisable as similar, but still show certain differences. To point at the telling changes in target choice and their relevance to the surrounding social reality, the following section will describe the jokes that have survived. These differences can be elaborated on, if examining side by side the scripts that were used both in the 19 th and the 20 th century. This not only gives an overview about the switch in the joke format, but also about the directions of change in target choice. The types that have survived are often not straightforward continuations of the old scripts but modified and adjusted jokes resembling the old folk jokes in logical mechanism, script opposition, setup, or in combination of these aspects (for explanations of the different levels of joke components and their hierarchies, see Attardo \& Raskin 1991, Ruch et al.1993). It will be interesting to see how they have been modified and what can be the reasons behind that. In this section, I will compare the old folk jokes with the punch-lined jokes (jokes from pre-1910 and post-1950s), without specifically emphasising the difference between the Soviet times and the post1990 era. The distinction of these will be an issue of the section discussing the recent developments.

The most abundant type of stupidity jokes is about any kind of inaptness, inability to recognise the function of objects or the way things work. There are some devices that were relevant then and are now, such as guns:

Two men from Hiiumaa found a gun. None of them knew what it was so they decided to investigate. One thrust the barrel into the other's mouth and said, "Mats, you blow into it, I'll press it in the middle!" He pulled the trigger, the gun went off, and filled Mats' mouth full of buck-
A monkey and a horse are taking a walk. They find a gun. The horse looks down the barrel; the monkey plays with the other end. The gun goes off, and blows away half of the horse's head. The horse falls down, twitching. The monkey gets 
shot. "Mats, spit it out!" the other man cries. Mats can't spit any more. Mats doesn't even move.

(Eisen 1895/2002 No. 1: Laetud püss. [Loaded gun.] O. Hintzenberg, Tapa town, North Estonia.) ATU 1228. angry, "What's so funny? I got a bad fright!"

(Online Joke Archive: Meie Naljaraamat, 15.10.1997)

There are jokes where necessity makes people take desperate action so that it looked foolish in its absurdity in an earlier time and still does today.

A Hiiu man was working on the mainland the whole summer, and got a bottle of vodka as a bonus. Winter was coming and he figured the cheapest way to survive is to buy a bag of peas and boil a weeks' ration at a time. One day the peas didn't taste too good any more. The Hiiu man had advice ready: took the bottle of vodka, and told himself, "Now look here, Hiiu man, you eat the peas, and I'll give you a sip of vodka as a reward!" He struggled to finish his peas, and when he was finished, he put the bottle away again and said, "Got you, I'm not giving you any!"

(Eisen 1895/2002 No. 29: Kaval hiidlane. [Cunning Hiiu man.] D. Pruhl, Metsiku village, Vihula parish, North Estonia.)
Jew Abraham was alone at home, Sarah was away, and he had to prepare his own food. He decided to make soup and eat it for the whole week. For the first few days the soup was a pleasure to eat, but on the fourth day it was not so tasty any more, and on the fifth day he ate it with great difficulty. On Saturday there was no way he could eat it. Stomach was upset. Abraham took a bottle of cognac from the cupboard, poured it into a shot glass and said, "You eat this, and I'll give you cognac!" Snorting and sputtering, he managed to shovel the soup down. He then poured the cognac into the bottle, took it back to the cupboard and giggled, "I conned you, Abraham!"

(Viikberg 1974)

False analogy that accentuates the target's naivety has always triggered amusement:

A man from Hiiumaa complained to a man from Saaremaa that he had a terrible pain
"I have a terrible pain in my eyes! What should I do about it?" 
in his eyes. He had tried all manners of ways to cure it, but to no avail.

The Saare man replied, "You idiot! When I had a toothache, I had my tooth pulled out, and the pain was gone in no time! You should have your eyes pulled out, and you'll see the pain go away immediately."

(Eisen 1901/2003 No. 21: Silm välja. [Eye out.] M. Rekkaro, Raiküla parish, North Estonia.)
"Well, I had toothache last year."

"And what did you do?"

"Pulled the tooth out!"

(Online Joke Archive: Eesti

Päevaleht online, 18.12.1997)

There are uneducated people who are unable to count money and do a simple calculation:

An old woman from the coast went to buy straw slippers. The merchant asked for half a rouble for the pair. The old woman started to haggle, "Let's make a bargain, I'll give you 70 kopecks! Half a rouble is far too much!"

(Eisen 1896/2002a No. 70: Ehk isand lepib. [Let's make a bargain.] J. Niinas, Risti rural township, West Estonia.)
An oil tycoon wanted to rent oilfields from the Indians and offered Winnetou $1 / 8$ of profit. Winnetow shook his head thoughtfully and said, "We want more. You give us $1 / 16$ !"

(Online Joke Archive: Erik Vallikivi joke collection, 1999)

A script of ethnic jokes closely tied with stupidity is that of slow wit, slow speech, and no speech at all and can sometimes be a marker of this slowness of character. The older version of this joke relies solely on the slowness interpreted as stupidity formula, whereas the contemporary variant has acquired allusions to ambiguous national stereotypes besides slowness. Specific stereotypes of drinking too much can be interpreted both negatively and positively, which makes the second joke sound almost like boasting, even if it primarily mocks the Estonians as poor communicators:

A Hiiu man often told his sons, "No need to chatter!"
Two Estonians go to a pub. They line up 7 vodkas on the bar and start drinking. 
Once the two sons were fishing at sea, and one of them drowned. The other came home, but said nothing.

After three days the father asked, "Where is Mats?"

The son answered, "Fell overboard and drowned!"

The father asked, "Why didn't you tell us?"

The son replied, "But you said yourself, no need to chatter!"

(Eisen 1896/2002b No 8: Mis kõiki tühja maksab rääkida. [No need to chatter.] J. Vitismann, Jüri village, Vihula parish, North Estonia.)
After a while, the first Estonian says, "You know..."

The other interrupts him, "Listen, did we come here to drink or talk?"

(Delfi, 23.05.2001)

As mentioned before, jokes accentuate the importance of normality, and both extremes (no power and status versus all the power and status) fall astray from the golden midway. Among the old joke tales and modern jokes alike, we find telling examples of how jokes depicted not only the peasants from the periphery but also the masters, although the joke-tellers were definitely of lower status (see Davies 1998: 93, who has also noticed that unjustified power often results in stupidity jokes). In the following comparison, the contemporary joke follows the old model in target choice (a peasant versus the master), not a very frequent cast of characters in recent ethnic jokes.

A man from the coast was heading inland. On his way, he meets the landlord who asks where he is coming from. "I come from below!" (meaning: from the coast). "From hell, then?" the master is curious. "Yes, that's right, straight from hell!" the man nods. "How is life down there? Better or worse than here? Were there any land-
The German said to the peasant, "Go to hell!" The peasant left and was gone for many days. On his return, the master inquires, "Where have you been?" - "Went to Hell, like I was told!" - "Did you see my ancestors?" - "Sure. Yours and mine. Master here, master there - your parents didn't have to do anything, just sat in 
lords?" The man answers, "Life was pretty good down there. I saw quite a number of landlords, all of them very well off. Once a master, always a master. They did not have to work at all." "What about the peasants?" the landlord is interested. - "There were plenty of those too, but life was not so good for them. Slaves they are here, and slaves they will be there. Landlords all sit around in big furnaces, but peasants have to work hard to keep the fire up!"

(Eisen 1896/2002a No. 77: Tulen alt poolt. [I come from below.] F. Freimann, Lehtse parish, North Estonia.) the furnace. My parents worked their guts out, shoving coal." (Online Joke Archive: Tanel Mägi joke collection, 19942000.)

A popular text with many variants during Eisen's time, the following joke has also survived until the present day. It is another good example of how insufficient or one-sided knowledge of how human organism works can sometimes be helpful, and hints that some are so stupid that they fail in everything, even in committing suicide:

A Hiiu man was fed up with life and wanted to hang himself. He tied the rope tight around his belly and suspended himself from a tree. Another Hiiu man happened to pass by. "What are you doing?" he asked. - "Hanging myself!" answered the man tangling from the tree. - "You daft man, is that a way to be hanged? Tie the rope around your throat first!" But the one up the tree replied, "Well, Mr Know-It-All, but when I tie it
A man was lying on the train tracks. A passer-by asked him, "Why do you lie here, you could be hit by a train?" - "That's what I'm counting on," the man answers. -"And what's that bundle by you side?" - "That'd be my sandwiches. I wouldn't want to die of starvation while waiting for the train."

(Online Joke Archive: Peedu Põllu joke collection, 19941998.) 
around my neck, I can

breathe no more!"

(Eisen 1896/2002a No. 16:

Hiidlase ülespoomine. [Hang-

ing the Hiiu man.] J. Niinas,

Risti rural township, West

Estonia.)

There are no similar punning jokes from the periods under discussion. In every edition published by Eisen, there was a small set of jokes based on language play (3-5 texts). This indicates that the difference between Estonian dialects did inspire some jokes in the 19th century. So did the mistakes that foreigners made while speaking Estonian (there are jokes on how Russians, Gypsies or Finns can understand and speak Estonian). Contemporary jokes do not actively use punning; also, Estonian is a language of few homonyms. Estonians mispronouncing or not being able to speak a foreign language is the subject of a few contemporary jokes (but it forms a considerable share of contemporary Russian jokes about Estonians), compared to the old folk jokes that mocked Estonians speaking pidgin German or Russian to improve their status. There are few jokes about foreigners failing to speak proper Estonian but since ethnocentrism is vanishing and in the globalising world people have started to realise that the knowledge of Estonian is not so self-evident, their number is diminishing.

\section{Revival of local targets}

In this section, the targets of the most recent ethnic stupidity jokes are tackled with. The Soviet times saw the importing of many new joke butts in Estonia, and so did the translated jokes from the beginning of 1990s (see Fig. 2 on p. 135). The influx of more universal stupidity jokes is continuing, but the tendency to "translate" the targets in accordance with the text has become more usual. There is an increasing interest in Latvians, Finns, Estonians themselves and the inhabitants of local peripheries as the stupid characters in Estonian jokes. Technical stupidity is often attributed to Latvians:

Latvian Air is on its first flight to Tallinn. "We are nearly there," Captain Renars says,"but what a short runway it is!" Renars and co-pilot Uldis still decide to risk landing the plane. With the engine roaring and tyres burning, the plane stops just a few inches from the end of the runway. The crew and passangers all sigh with relief. Renars looks out of the 
window and exclaims, "Well that sure is the shortest runway I've ever seen!" - "Yup," Uldis agrees, looking from side to side. "But look how wide it is!" (Delfi, saarlane, 02.01.2003, 13:02)

A Latvian news story. On Tuesday evening, there was a major power cut in downtown Riga. Hundreds of people were trapped waiting for the escalators to start moving again. (Delfi, vallerii, 10.11.2004, 14:13) ${ }^{6}$

The typical format of universal stupidity jokes, the question and answer, is a short and easy formula that is especially frequently used in computer-mediated jokelore. The conundrum joke is a quasi-riddle that expects no answer (e.g., Chiaro 1992: 69). This is also the main form of ethnic jokes about Blacks; these jokes were popular in Estonia at the beginning of the 1990s. ${ }^{7}$ They usually represent straightforwardly unpleasant and even aggressive stereotypes, the following being a mild exception to the rule.

- What do you get when you cross a donkey and a turtle?

- A Latvian with a helmet. (Delfi, Combainer, 13.10.2004 19:56)

The Finn is also an occasional character in stupidity jokes, sometimes replacing the Latvian in the same jokes. Some of these display neighbourly affection also through sexual allusions, as in this ethnic stupidity joke (in variants, a Latvian replaces the Finn):

A Finn and an Estonian are on a deserted island. Finally they get really desperate for sex and start to look for a way to satisfy their needs. Suddenly they come upon a deer, its head stuck firmly between two trees. The Estonian gets down to business. Finished, he tells the Finn, "OK, now it's your turn!" The Finn sighs, steps next to the deer and puts his head between the two trees. (Delfi, mz, 13.09.2000 08:55) ${ }^{8}$

In general, the Finns are becoming a less frequent joke target than the Latvians (even though in the overall statistics of the most popular Estonian online joke portal since 2000, Delfi Naljaleht, provides a larger number of jokes containing the word "Finn" (278) than "Latvian" (144)). At the beginning of the 1990s, the great number of Finns visiting the centre of Tallinn, or vodka-tourists as they were called, were considered a problem by the local population. This resulted, among other things, in a wave of stupidity jokes.

A Finn has a brain tumour, and it has to be operated on. He needs new brains. The doctor says, "You can choose the brain you want. Estonian brain is the cheapest, 1,000 EUR per gram. We also have Russian brains, for 2,000 EUR per gram. But if you really want a Finnish brain, you'll 
have to pay 10,000 EUR per gram." The Finn starts protesting: how can the Finnish brain cost so much, it's not THAT much better. The doctor replies, "No, it's not that - do you know how many Finns we need to get just one gram?" (Delfi, M\&M, 04.07.2000 13:52)

A Finn is hitchhiking on the Tallinn-Pärnu highway. An Estonian offers him a ride. The Finn asks, "Is Tallinn far away?" - "Not really," the Estonian answers. They drive for an hour, then the Finn asks again, "Is Tallinn still far away?" The Estonian replies, "Yes, now it's far away." (Online Joke Archive: Meie Naljaraamat, 01.09.1998)

In recent years, the Finn has become the target of jokes built on more specific stereotypes (e.g., when being boiled by a cannibal, a Finn asks for some cold vodka as it was getting quite hot in the kettle - a reference to the Finnish sauna culture), and the similarity of the two Fenno-Ugric languages inspire few language jokes.

Of local targets, aside from the very general "Estonian" as ethnic marker, the most popular is still the Hiiu man. Also a universally known joke text, this joke is more a trickster joke than a stupidity joke, and in many cases that is what has became of the Hiiu man in modern jokelore.

A Hiiu man goes to the clinic. He complains to an attractive female doctor, "I think I have three testicles." The doctor asks him to undress, looks and examines thoroughly, but sees nothing unusual. She asks the nurse to come and look at it too. They examine the man together, but conclude he's only got two and there are no anomalies. The Hiiu man gets dressed, thanks the doctor and leaves. On his way out he meets a friend, who is curious about what he was doing at the doctor's. "I had some spare time before the ferry left," the Hiiu man replied. "So I came here to have my balls massaged." (Delfi, 17.05.2001)

There are some modern (most often former blonde) jokes about Kilplased, even though this pseudo-ethnic group has never been a very popular target. It seems that by today the quasi-nation symbolises the Estonian numskull in general.

Why does the wall fall when a Kilplane [previously: blonde] props himself up the wall? - The wiser gives in.

Why did Kilplane [previously: Chukchi] laugh, running around the mountain to escape from the polar bear? - He had outrun the bear by three laps.

(Online Joke Archive: http://www.feim.ee/nali.php?p=19) 
Jokes that target the Estonian himself very often juxtapose him with other nations (e.g., Finns in the examples), especially in the form of three-nation jokes:

Once upon a time there were a blind Latvian, a deaf Lithuanian and a paralyzed Estonian. One day, God comes to them and says that everyone is granted one wish. They enter a room. In a few minutes, the Latvian runs out and screams, "I can see!" A while later, the Lithuanian is jumping around, cheering, "I can hear!" After a short while, the Estonian comes out and shouts happily, "I got new wheels for my wheelchair!" (Delfi, 23.10.2002)

Heightened interest in the local target, most often the fellow Estonian, also appears in contemporary three-nation jokes. Astrid Tuisk (2008) in her analysis of the targets of this specific sub-genre of ethnic jokes compared the threenation jokes from two quite close periods, acquired in the course of school lore collecting campaigns in Estonia in 1992 and 2007. The interval of 15 years proved long enough to see changes in the collected jokes. From among all the topics that the open-ended questionnaires from the two campaigns covered, jokes varied the most (Voolaid 2007). Recent plays or ghost stories told by school children resemble very much the plays played and stories told at the wake of the Estonian republic, whereas jokes have a remarkably different focus than before. There are still few Juku (Little John) jokes, ethnic jokes (including three-nation jokes), and an increasing amount of animal and sexual jokes, but political jokes are almost non-existent, though these were the dominating category in the 1992 campaign (the jokes collected in 1992 consisted largely of Soviet jokes). The three-nation jokes were present in the results of both campaigns, and the genre is very traditional and stable. At the same time, Tuisk (2008) notices some important changes that are telling in the context of this study. Namely, there is a growing tendency of showing the Estonian character as stupid:

A Russian, a German, and an Estonian are stranded on a deserted island when they find a Genie. Everyone is granted one wish. The Russian wants to get home to Moscow and a case of vodka bottles. The German wishes to go home to Berlin and asks for a prettier wife. The Estonian asks for a lot of beer and his two friends back. ${ }^{9}$

or sometimes dirty:

A Russian, a German and an Estonian are in prison. The one who can stand the smell of a camel for the longest time, will be freed. The Ger- 
man manages to stay there for some minutes and then rushes out, the Russian for some hours. The Estonian has stayed in the tent for some time already when the camel rushes out, screaming, "I can't bear the smell any longer!"

There are not many recent jokes that positions Russians on the loser's slot, this position is now occupied by the stupid Estonian. Of the few jokes in which the old power relation has been maintained, the most popular is the airplane joke showing that the amount of Russian ethnic immigrants and their integration was a problem then and is still an issue, even for schoolchildren.

A Russian, a German and an Estonian are flying a plane when an engine breaks. Each has to throw something down. The Russian throws a bottle of vodka - they have enough of it. The German throws a pack of cigarettes - they have enough of it. The Estonian throws the Russian down - they have enough of them.

Despite the first impression of straightforward self-deprecation, the Estonian is also the character of many self-boosting three-nation jokes. Tuisk (2008) gives examples of several jokes that depict the Estonian as the winner. The positive ("winning") jokes have retained the same positive hero (the Estonian), but the derogating jokes have gained a new twist by introducing the Estonian as the stupid one instead of the former butts (Russians, Chukchi, etc). Frequent are also jokes where winning a three-nation competition is of very dubious quality. These are jokes with scatological allusions: the contestants have to climb the stairs without defecating, or cross the bridge without blowing their nose, etc. The "winner" is then the one who manages to pass the test, but more than being delighted in his obscene victory; children laugh at the dirtiness of the mock hero - who is, very frequently, the Estonian himself.

The character on the last slot may not always be the target, but instead the winner. At the same time, as seen from the last examples, the winner does not unequivocally gain the upper hand in the battle - his victory is often smelly, strange, or awkward. The Estonian acts a part in all of the positions of the three-nation joke, he may be the target, the hero, or the mock hero. Thus it cannot be concluded that the Estonian as a target is solely a national laughing stock. Instead, the generalised interest shows that the Estonian as a character in our jokes (as a target or the one gaining more or less ambiguous victory) is becoming more and more relevant much like in the ethnic jokes from 1991 until the present day. 


\section{DISCUSSION}

The previous examples gave an overview of Estonian stupidity jokes throughout the past century. Looking at the targets of stupidity jokes in these different periods, we see that there has always been confusion about who would be the most suitable one. Further towards the end of the 20th century, the number of new targets is growing, their geographical location is diversifying. Christie Davies, who acquired his data and conclusions as a result of cross-cultural comparison, has described the typical butts of stupidity jokes in a number of countries worldwide, and formulated universal rules of target choice on the basis of that (Davies 1990, 2002 and elsewhere). Interestingly enough, the theory accounts for most of the old folk jokes found in Eisen's collections, the earliest period of our study. The stupid characters are true outsiders with a peculiar speech and seemingly backward habits (Setu, Saaremaa and Hiiumaa, people living on the coast Fig. 1, map).

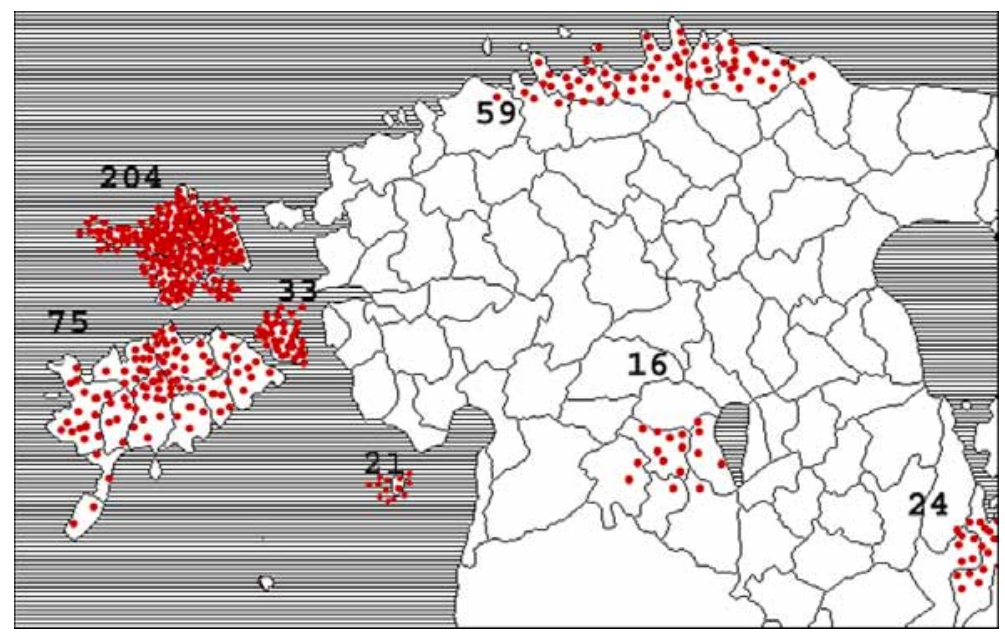

Figure 1. Joke targets in Estonian old folk joke tales (Eisen, 1895-1910). Number indicated the amount of joke texts with the particular target. 204: Hiiu man, 75: Saare man, 59: man / woman from the coast, 33: Muhu man, 24: Setu man, 21: Kihnu man, 16: Mulgi man. ${ }^{10}$

In the old joke tales, the targets are mocked for their slowness, for being unable to understand simple rules necessary for a successful (country) life, or other characteristics. Stupidity jokes are in the majority, ${ }^{11}$ and there are several targets (which vary in different regions; although based on the results of comparing the amount of sent jokes and the location of their senders, jokes about Hiiu men came in from all around Estonia). In Estonian old folk jokes and early punch-lined jokes, targets are peripheral groups with funny speech 
and perceived backwardness. Foreigners are in a clear minority and limited to those who have had direct contact with Estonian natives (travelling Gypsies, Russians, Germans and Jews, less often Finns). Their vice is usually more specific than just universal stupidity (Gypsies are cunning but lazy, Russians speak a strange language and knowing a few words of Russian is necessary, Jews are stingy and materialistic, etc). There are no completely irrelevant stupid/dirty/strange characters like the Blacks, Armenians or Americans present in Estonian jokelore after the 1950s.

Even more curiously, the rules of target choice cannot be applied to SovietEstonian ethnic jokes about stupidity (1950s-1991 in our sample). First of all, there are no traditional stupidity jokes in the Soviet period, only politically loaded ones. Secondly, the scope of targets moved to the East and in part also to the West. The pan-Soviet enemy constructed by the official media was the USA. It is obvious that the relationship between Estonians and Russians, Chukchis, or Ukrainians was not that of cultural closeness, perceived differences in living standards, or even occupying the same geographical location. At the same time, there are indications that at least children telling jokes about the Chukchi were not even aware that this is a nation, and answered that the jokes are about a boy called Chukchi (Tuisk 1995: 73, in an article about the 1992 school lore collecting campaign). The analysis of Estonian joke targets (Laineste 2005, reprinted in Fig. 2) shows that the local targets disappeared completely during the Soviet times, and were replaced by a number of new ones which, arguing from the stand-point of everyday reality and problems, was choice were absolutely justified. Towards the end of the 1990s, the importance of Soviet targets diminished, but again many new nationalities

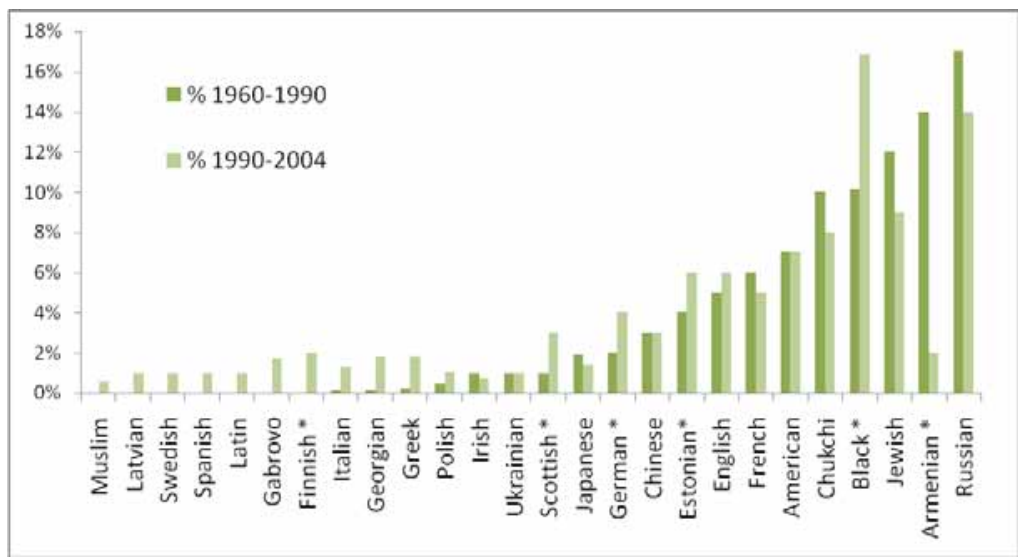

Figure 2. Targets of Estonian ethnic jokes, 1960-2004. The nations marked with an asterisk (*) show a statistically relevant change in popularity (percent improvement coefficient was calculated, and an increase or decrease exceeding $25 \%$ was considered significant). No distinction was made between local ethnic groups in the case of "Estonian". 
(Finns, Greek, Gabrovo, Latvian, Swedish, Italian, Japanese, Arab, Latin American, and others, whose proportion in the corpus was less than 1\%) were introduced (mostly as translations of those used by the English-speaking world).

The universal rules of target choice seem to be again valid, and increasingly so after 2000, when the newly regained independence in Estonia has necessitated "updating" the jokelore. Already visible from the illustration that compares Soviet and post-socialist joke-butts (Fig. 2 on p. 135), the amount of jokes about Estonians themselves have risen. Jokelore has transformed from mocking Soviet power and nations into a tradition that strives to find other, more relevant targets, laughing now at our own stupidity or that of our close neighbours (Latvians, Finns).

While in the Western world the stable nation states have created longlasting and fossilised stereotypes of the most stupid people (usually kinsfolk: Irish, Belgians, Vallonians, Karelians, etc), the now post-socialist countries were for a long time part of the unified "joke circulation" of the Soviet Union. They shared the fears, economic hardships, and even joke targets. This very fertile and long-lasting Soviet joke tradition in most post-socialist countries is an exception to the rules of target choice postulated by Davies, and should be given attention to in order to revise the universality of the theory. The question of discussion is why the 19th-century targets were non-existent during the Soviet times, who replaced them, and what has made them to return.

Drawing from the analysis of jokes from the three periods, several conclusions can be drawn.

First of all, targets have systematically been changed from more specific into less specific, from geographically close into less close. In general the tendency to use less ethnic markers and more neutral or general ones ("man", animals, officials) is visible. So a Hiiu man, a coastal woman, an Estonian have became a man, an animal, an American. Also the proportion of ethnic jokes has fallen consequently (see also Laineste 2008). Ethnic markers have been replaced with more general vocational and gender markers.

Even in old folk jokes, there was not one strong and nationally recognised joke target that could have survived under the influx of Soviet jokelore. Hiiu and Saare men are making their comeback most forcefully, but during the Soviet times the target was completely forgotten.

Next, examining the Estonian joke tradition does not support the fact that the direction of joking is universally directed from the centre (the "better-off"), towards the periphery, where the backwardness of its inhabitants is notorious. ${ }^{12}$ In the earlier times, the "normal" lifestyle was mostly connected with rural, not city life. Few jokes were sent from people from Tallinn or Tartu the majority of jokes were sent in by people living in Hiiumaa, Saaremaa, 
Tapa, or other peripheral areas. Perhaps the most widely known mutual joke exchange was between the islands of Saaremaa and Hiiumaa. That is to say, Estonians used to laugh at the regional differences, and that was not necessarily linked to the qualitative differences in status, as the living standards in Hiiumaa and Saaremaa, for example, were broadly the same. The notions of centre and periphery were muddled, because in the $1890 \mathrm{~s}$, life revolved around the local and regional rather than a state level. Also in the Soviet times, there was no local centre of power, and the pan-Soviet division was between the centre of Moscow and the periphery of all the rest. Regardless of this, the ethnic-political joke of the time was quite often targeted at the centre of power. The power was represented by Russians, which was at the time the most common joke target in Estonia. An exception of this general direction are the jokes about different peripheral nations (in pan-Soviet sense: Chukchi as the most famous, but also Ukrainians and a few others) who were not actually peripheral to Estonia but to the whole Soviet Union. Therefore, the Soviet Union introduced new pan-Soviet targets who by theory should have no particular appeal to Estonians. Soviet joke tradition replaced all local targets, being more vital, more topical.

Another change in jokelore is coming about in Estonia as the Soviet jokes are diminishing and old local targets are slowly re-entering jokelore (Estonians themselves are becoming more popular targets, as are several local numskulls like Hiiu, Saare and Setu men; also the frequency of Finns and Latvians is on the rise). We have stupidity jokes that were not told in the Soviet times, and even if the joke itself is translated, the targets are switched into more appropriate local characters, resonating better with Davies's theory of target choice. Russians have rarely been targets of straightforward stupidity jokes in Estonia but Finns and Latvians as joke targets were to some extent also present in Eisen's joke collections. The Finnish would be the most likely choice of target for stupidity jokes (because of culture, language and location, even though economic tensions and relative centre - periphery distinction has usually perceived the Estonians as the "younger brothers" of the Finns), but it seems that Latvians have bettered them in this competition. There are many universal stupidity jokes featuring Latvians or Finns, sometimes even interchangeably. From local groups, the same geographic locations as in the 1890 s are giving most jokes on stupidity: Hiiu, Saare and Setu.

And finally, Estonians are eager to look for their very own and specific group to whom stupidity jokes could fit. To a growing extent, these groups are Latvians, Finns, and most of all Estonians themselves. The same groups that were mocked a century ago are now re-emerging in our jokelore: Saaremaa, Hiiumaa and Muhu islanders, Setu and Mulgi men from South Estonia, etc. 
All the post-1991 popular targets (Europeans, Blacks, and more exotic nations) are losing their topicality.

Besides the content, jokes as a genre have gone through even greater changes in terms of their structure.

\section{DEVELOPMENT OF UNIVERSAL STUPIDITY JOKES}

There has been a need for increasingly universal/global sense of humour - in the 19th century, every folk joke was embedded in a certain social situation and usually assigned to a neighbouring village, or an outsider from the same village. The "market" for the punch-lined joke with easily interchangeable targets was not born yet. There were joke tales that used similar plots for mocking different groups in various countries (e.g., some of the typical numskull stories in Uther's index), but this was nothing like the contemporary, fastspreading universal stupidity jokes that gained simultaneous popularity all around the world. In the modern globalising world, stupidity proved to be the universal characteristic that could be pinned on almost anyone. There are a number of stupidity jokes that are known with minor modifications throughout the Western world. The increasing popularity of the stupidity joke seems to accompany the development of the short and punch-lined format, which was among other things motivated by the commodification of the genre (a process elaborated by Wickberg 1998).

This is closely tied with another aspect of the issue, namely the interactions of the universal stupidity joke and the nation-specific ethnic joke. Though older stupidity joke tales were numerous in the earlier tradition before the short punch-lined joke became into being, the choice of targets in most jokes relied on actual contact with the targeted group and was thus quite specific (there were a lot of jokes about Hiiu men who travel to the mainland for work, Saare men are known for the poor quality of their workmanship, and the Gypsies eat inedible leftovers that they consider to be proper food, etc). The joke tales were mostly connected to specific ethnic stereotypes, and even if there was the obvious stupidity of the ethnic group underneath, the top layer displayed a number of more individualised characteristics derived from personal contacts or collective beliefs. Even if the plots were borrowed, there was a clear tendency to "translate" the targets in addition to the jokes themselves.

The jokes that use these most basic oppositions to maintain the ludic difference between "us" and "them" have developed in order to claim global spread. Some of these have formed joke cycles. Their reusability and quite homogenised form (e.g., the question and answer format) prompts to use the whole 
set, not just certain texts, besides, the idea they carry is identical in all cases. Serial jokes can be used without further modification in the context of ethnic confrontations (Kvideland 1983 about the Scandinavian joke war) or after catastrophes (Challenger jokes - Smyth 1986; Princess Diana jokes - Davies 1999; Chernobyl jokes - Fialkova 2001; WTC - Csaszi 2003, Ellis 2001). Many nations assert in the jokes that some ethnic groups (Polish, Jews, Russians, Estonians, etc.) would fail to change an electric bulb. Even if some nationspecific trait is present, it is never as strong as in stereotyping jokes thatare rendered meaningless if the target is changed. The light bulb joke cycle is the most widespread of the jokes cycles of universal stupidity: besides being ethnic, they can be about vocational subgroups (policemen), gender (blondes), or other specific subcultures in the society (musicians, and others).

National stereotypes are heuristics that organise the world into categories, but the categories they present are more varied, more complex than those of stupidity jokes, which mainly rely on "stupid versus smart", or the even more conventional opposition of "good versus bad". To "get" a specific joke, one must first go through a series of associations and available national stereotypes. $\mathrm{He}$ must realise that behind the specific script of hyper- or hyposexuality, for example, is the general assumption that the "other" strays from normal/ is bad/ is stupid in essence. Serial jokes, on the other hand, present the listener with a "chewed" pair of oppositions ready for "instant digestion". It does not take too much time and energy to understand the joke. The most simple and basic oppositions have huge potential for popularity worldwide.

The field of connotations and allusions in the case of specific jokes is more ambiguous, as the "bad" is not univocally negated, even if it is abnormal. In the case of jokes on sexuality or drinking, for example, the target may well be proud of its abilities instead of being embarrassed, and the joke may be borrowed into the jokelore of the target as not derisive of but complimenting the group.

The spread of serial jokes has intensified with the proliferation of electronic communication. It fits with several characteristics, possibilities and features provided by the new form of interaction. Traditionally, the jokes were transmitted orally. Remembering the joke required mnemonic techniques, including knowing the beliefs and attitudes, and awareness of the "us" and "them" distinction. Every joke was easily modifiable in the course of representation. In the case of Internet jokes, the text appears in written form, which makes it more rigid. Copying jokes from one site and posting them to another is a regular practice which keeps multiplying identical jokes on the web and is subject to a few modifications. The highly stereotyped form allows instant admission to the second level, its oppositions, without any critical examination of the 
suitability of the new target. The form is standardised, and often uses words like building blocks: anyone can compose a stupidity joke without any knowledge of the target. It creates an atmosphere of similarity and familiarity. Already after the first line, the listener can enter the play frame that is much more understandable than the jokes in which not knowing the specific stereotypes may ruin the amusement.

The shortened form has thus dictated the change in content and vice versa. Oppositions strive to be more readily available, more forceful, dwelling on the universal extremes from the golden midway. All this has been reinforced by globalisation, in the era when jokes travel faster and need to be adapted from one nation to another, between languages and over cultural contexts. Although the cultural norms and expectations of humour may vary, the serial stupidity jokes seem to fulfil most of them for most nations. Thus the stupidity jokes are the extreme manifestation of a 'commodified' (a term borrowed from Wickberg 1998) canned joke. Even if we do find some similar approaches to human folly in both the old folk jokes and in contemporary jokes, the availability of oppositions, impersonality and universality of the latter are the imposed requirements for a (globally) successful joke text. In addition to the former observation, this is another reason why there are not many similar scripts in the earliest and latest datasets of Estonian jokes.

\section{CONCLUSION}

As Davies's theory claims, there are few universal rules to decide the identity of the joke-butt, and these have evolved due to long-term cultural, economic and other conditions. What it does not account for are the political conditions that have a profound effect on ethnic joke targets.

Politicisation of ethnic jokes results in a tradition of ethnic jokes that do not bend under the rules of target choice postulated by Davies. It seems necessary to take the wider macro-context into account. Not only are the economic and cultural position of the target necessary to decide its popularity, but also the prevailing political situation and opinions play along. In the case of a totalitarian regime, some global (and locally quite inexplainable) joke targets were introduced in Estonia. Stupidity was not just a silly, mirthful and laughable characteristic, it was politically laden with despise towards the oppressors (and one joke could do both: in Chukchi jokes, the stupid character was Chukchi, but the context of the joke often framed an opposition with the source of his misery, the regime, and its henchman, the Russian). The presence of political oppression muddled up the emic target choices, bringing in the new groups 
and erasing others that were originally valued by Eisen as "authentic" Estonian joke-butts. The recent rejection of an otherwise versatile and infamous Soviet joke tradition is an indication of a search for more relevant targets, and it seems that the last choices of targets partly follow the universal rules of target selection in stupidity jokes. In fact, the two competing impulses of rehabilitating the popular numskulls of old joke tales and focusing on the closest neighbours are only partly backed up by the previous theory. With Latvians, there are no linguistic similarities. The Finns who speak a similar language have always been better off than Estonians. It seems that the theory of target choice applies only in the case of a limited number of nations that represent a more ethnocentric worldview, and (cultural and economic) peripheries will adopt much from the centres of joke production. This means that Estonians borrow jokes from the nations with who they have closer relationship for the time being: German (folk tales and Schwänke by the Grimm brothers) in Eisen's collections, Russians in the Soviet times, and English, Americans, perhaps also Finns in contemporary jokelore. We could call it a reference group for jokes. Peripheries are usually more prone to adopt tradition modifying it in the process. At the same time they retain their previous folklore, resulting in an exciting mix of mainstream and unique. Estonia has long been a periphery of different political and economic formations: of several hegemonies, of the former Soviet Union and the present European Union. Estonia forms a distinct exception to the theory formulated regarding primarily the central tendencies in the target choice of the globally "central" countries.

Generally speaking, Davies's theory is missing a sufficient political dimension to account for the totalitarian joke targets. It might also benefit from realising the relative nature of the categories/ dimensions of better and worse off, of centre and periphery, which are difficult to appoint to countries without being biased, and which are to a great extent perceived qualities as opposed to more definitive features. Even though the line of argument concerning the borrowing and blending jokes from regions that set a cultural and other role model is interesting, there are certain drawbacks: claiming that Estonia is the periphery to other, globally more recognised countries does not help to explain the number of jokes on Finns, or previously on Russians, as being borrowed only because these were the perceived centre - there is always free choice involved. Besides, this would turn the boards also with the general rules set by Davies's theory, maintaining that it is particularly the centre that tells jokes about the periphery. It would be useful to make comparative research between post-socialist countries, keeping in mind the continuities and disruptions in the tradition. 
Cultural contacts and periods of intensive political, economic and other societal changes indisputably do affect folklore. We see this also in Estonian jokes where these transformations are highly visible because of the large scope of changes. These took place in a relatively short period of time, and we can trace back the course of the changes. The recent trends of globalisation are also changing the present jokes. The 1990s' turn towards the West resulted in a great influx of foreign, mostly English loans, but more recently we see again a creative adaption of joke scripts to meet the need for self-identification.

At all times, jokes have been a conscious choice. The focus has always been on the relevant issues: in the earliest times described here, the main focus was the neighbours or the inhabitants of the neighbouring parish. During the Soviet times, people were most concerned with the politics and ethnic groups responsible for the political oppressions, and as the borrowed Soviet jokes were critical towards the regime, there was no need for more elaborate and freerunning alterations or modifications of these jokes. After Estonia regained independence, the main focus was the quest for a new identity, which in jokelore found expression in a rejection of old Soviet jokes and even turning back to the 19th-century models - at least in terms of target choice. The creation and alteration of traditions is thus closely connected with everyday reality and the political context influencing this.

Taking all variables into account, the theory of Christie Davies on ethnic humour does not fully apply to the choice of targets of Estonian ethnic jokes. This discrepancy is due to the strong influence of Soviet jokelore on Estonian jokes during the second half of the 20th century, and to a different nature of the relationship between peripheral countries as opposed to the interethnic relations of Central Europe. Contemporary Estonian ethnic jokes are striving to re-discover the joke targets familiar from 19 th-century joke tales. The analysis throws light on the relationship of jokes and the society in which they are told. Jokes are dependent on the immediate political, cultural, economic and other environments, shaped by relevant issues of the period like the quest for national identity.

\section{ACKNOWLEDGMENT}

The article was supported by Estonian Science Foundation grant No. 6759 (Folkloorne anekdoot tänapäeval: postsotsialism-internet-kognitiivsus). 


\section{COMMENTS}

1 Matthias Johann Eisen (1857-1934) was an Estonian folklorist, best known for his folklore collection work and compiling a systematic typology of Estonian folk tales.

2 The axiological division of the centre ("better off") and periphery ("worse off") does not function here in an unambiguous manner. Soviet Estonia (like other Baltic states) was usually regarded as a nearby and prosperous "foreign" country by people living in Russia.

3 This is, in a way, also an instance of the weak laughing at the powerful: a protest against fate, nature and other unbeatable forces in life. These jokes vent the anxiety of the mishaps and misery of the little man, showing that there are ways one can outplay the seemingly invincible forces. There are also instances when the better-off can be stupid (Estonian jokes about the Finnish), and the worse-off can be a clever trickster (old Estonian joke tales, but also Soviet and post-socialist jokes about the Russians; e.g., the three-nation jokes - see the chapter on targets of three-nation jokes).

4 Other genres in the older layers of folklore often included ethnic references as well, whereas in contemporary folklore ethnic markers have been replaced with other, more generalised tags (male/female, etc.) (see Mintz 1996: ethnic humour being the most manifested on stage in 1890-1910; Allen 1990: fewer and milder ethnic nicknames than at the beginning of the 20th century; Cray 1962: 28 ethnic naming has diminished from derogatory to derisive, e.g., more aggressive to mildly aggressive; Rappoport 2005: ethnicity does not carry the same weight than at the beginning of the century).

5 The joke is popular on Indian web sites, but it frequently also targets Irish and other nations.

${ }^{6}$ On the Russian web, the joke is depicting Finns and Estonians above others and can thus be categorised as a joke on stoical patience (besides stupidity).

7 These question and answer jokes circulated mainly on the Internet, being posted at discussion boards or other public sites in sets of 10-20, sometimes even more jokes at a time (a feature similar to blonde joke cycle). Very aggressive in content, they were mostly translated from the English-language web. These serial stupidity/dirtiness jokes were also later used in a warfare between two media figures wishing to discredit one another (Joon 2003), and in this meta-joke form even won attention, precisely because of the absurdity of its reuse.

8 On the Russian web, the targets of this wide-spread joke are Estonian and sometimes Latvian.

9 The following three examples are cited in Tuisk 2008.

${ }^{10}$ It is a noteworthy tendency that all folklore, including joke tales, are usually more variegated/diversified in the peripheries and duller/monotonous/less varied in the centre (Krikmann 1997). In terms of unique texts as well as in terms of intensity (number of texts), South Estonia displayed the greatest variety. 
${ }^{11}$ In old folk tale tradition, the driving force/animating principle of the tales involving a conflict and its solution is of axiological character: In the case of fairy tales and legends, the power is nested in virtue, and in the case of animal tales, trickster stories and joke tales, the possession of intellect grants the victory. That makes stupidity the main laughing stock in old folk jokes, either in jokes that juxtapose the clever and the stupid, or in jokes where the stupidity of the actor in itself, without any help from more or less hostile fellow people, is sufficient to cause failure or suffering (Krikmann 2003: 168).

12 There is counterevidence on the direction and asymmetricality of the joking relationship from Scandinavia, where Danes, for example, tell jokes about the Germans and Swedes, even if the target is perceived as more powerful and successful. At the time when Denmark was perceived as more powerful, there was no animosity against the Swedes (Bondeson 2005), but when their power over Danes grew, stupidity jokes about the Swedes evolved.

\section{REFERENCES}

Allen, Irving L. 1990. Unkind Words: Ethnic Labelling From Redskin to WASP. New York: Bergin \& Garvey.

Attardo, Salvatore \& Raskin, Victor 1991. Script theory revis(it)ed: joke similarity and joke representation model. HUMOR: International Journal of Humor Research. Vol. 4, No. 3/4, pp. 293-347.

Bondeson, Ulla V. 2005. Crime and Criminals in Nordic Countries. Society. Vol.42, No. 2, pp. 62-70.

Chiaro, Delia 1992. The Language of Jokes:Analyzing Verbal Play. London: Routledge.

Cray, Ed 1962. Ethnic and Place Names as Derisive Adjectives. Western Folklore. Vol. 21, No. 1, pp. 27-34.

Csaszi, Lajos 2003. World Trade Center Jokes and Their Hungarian Reception. Journal of Folklore Research. Vol. 40, No. 2, pp. 175-210.

Davies, Christie 1990. Ethnic Humor Around the World: A Comparative Analysis. Bloomington: Indiana University Press.

Davies, Christie 1998. Jokes and their Relation to the Society. Humour Research Series. Berlin, New York: Walter de Gruyter.

Davies, Christie 1999. Joke on the Death of Diana, the Princess of Wales. In: T. Walter (ed.) The Mourning for Diana. New York \& Oxford: Berg Publishers, pp 253271.

Davies, Christie 2002. The Mirth of Nations. New Brunswick: Transaction Publishers.

Dorst, John 1990. Tags and Burners, Cycles and Networks: Folklore in the Teletronic Age. Journal of Folklore Research. Vol. 27, No. 3, pp. 179-190.

Eisen, Matthias J. 1909/2003. Eesti Rahvanali. [Estonian Folk Joke.] Available at http://www.folklore.ee/rl/pubte/ee/vanad/eisen/ernali/sisu.html, last accessed in Dec 2008.

Ellis, Bill 2001. A Model for Collecting and Interpreting World Trade Center Disaster Jokes, New Directions in Folklore. Vol. 5 (Oct 2001). Available at http:// www.temple.edu/isllc/newfolk/wtchumor.html, last accessed in Dec 2008. 
Fialkova, Larisa 2001. Chornobyl's Folklore: Vernacular Commentary on Nuclear Disaster. Journal of Folklore Research, Vol. 38, No. 3, pp. 181-204.

Joon, Liisi 2003. Anekdoodid ideoloogia tööriistana: "Hallaste ja Murutari juhtumi" analüüs. [Jokes as the ideological tool: The case study of I. Hallaste and K. Murutar.] In: M. Hiiemäe \& K. Labi (eds). Teekond. Pro Folkloristica. Tartu: Eesti Kirjandusmuuseum, pp. 15-32.

Krikmann, Arvo 1997. Sissevaateid folkloori lühivormidesse, I. Põhimõisteid, Žanrisuhteid, üldprobleeme. Tartu: Tartu Ülikooli Kirjastus.

Krikmann, Arvo 1999. Naljandite tüpoloogiast. [On the Typology of Folk Humour.] Tartu: EKM Dept. of Folkloristics.

Krikmann, Arvo 2003. Puändita naljandite struktuurist. [On the Structure of Jokes without Punch-Line]. Keel ja Kirjandus. No. 3, pp. 161-177.

Krikmann, Arvo 2006. Jokes in Soviet Estonia. A paper presented at the 18th ISHS conference in Copenhagen, July 2006. Available at http://www.folklore.ee/ kriku/ TRANSPORT/KrikmannSovEst.pdf, last accessed in Dec 2008.

Krikmann, Arvo 2008. "ATU” Jokes: Old and Abandoned. A paper presented to the ISHS 20th annual conference hosted by the University of Alcala (Alcala de Henares, Madrid, Spain). July 7-11, 2008. Available at http://haldjas.folklore.ee/ kriku/ HUUMOR/KRIKMANN_ATU_ready.pdf, last accessed in Dec 2008.

Kuipers, Giselinde 2002. Media Culture and Internet Disaster Jokes Bin Laden and the Attack on the World Trade Center. European Journal of Cultural Studies, Vol. 5, No. 4, pp. 450-470.

Kvideland, Reimund 1983. Den Norske-Svenske Vitsekrigen. [The Norwegian-Swedish War on Jokes.] Tradisjon. Vol. 13, pp. 77-91.

Laineste, Liisi 2005. Targets in Estonian Ethnic Jokes within the Theory of Ethnic Humour (Ch. Davies). Folklore: Electronic Journal of Folklore. Vol. 29, pp. 7-24.

Laineste, Liisi 2008 (in press). Post-Socialist Jokelore: Preliminary Findings and Further Research Suggestions. Acta Ethnographica Hungarica.

Mintz, Laurence E. 1996. Humor and Ethnic Stereotypes in Vaudeville and Burlesque. MELUS. Vol. 21, No. 4, pp. 19-28.

Oring, Elliott 1992. Jokes and Their Relations. Lexington: The University Press of Kentucky.

Rappoport, Leon 2005. Punchlines: The Case for Racial, Ethnic, and Gender Humor. Westport, Connecticut \& London: Praeger/Greenwood Publishers.

Ruch et al. 1993 = Ruch, Willibald; Attardo, Salvatore \& Raskin, Victor. Toward an Empirical Verification of the General Theory of Verbal Humor. HUMOR: International Journal of Humor Research. Vol. 6, No. 2, pp. 123-136.

Smyth, Willie 1986. Challenger jokes and the humour of disaster. Western Folklore. Vol. 45, No. 4, pp. 243-260.

Tuisk, Astrid 1995. Lipitud-lapitud. Tänapäeva folkloorist. [About Contemporary Folklore.] Tartu: Estonian Literary Museum and Estonian Language Institute.

Tuisk, Astrid 2008. Kolme rahva anekdoot lastepärimuses. [Three-nation Joke in Estonian School Lore.] Presentation at the Conference of Folklorists, in January 2008, Kopra talu, Estonia. 
Voolaid, Piret 2007. Children and Youth Lore: Innovations and Traditions in Contemporary Society. Folklore: Electronic Journal of Folklore. Vol. 35, pp. 148-152. Available at http://www.folklore.ee/folklore/vol35/news.pdf

Wickberg, Daniel 1998. The Senses of Humor: Self and Laughter in Modern America. Ithaca: Cornell University Press.

\section{Joke collections}

Eisen, M.J. 1895/2002. Rahva Nali. [Folk Joke.] http://www.folklore.ee/rl/pubte/ee/ vanad/eisen/rnali1/

Eisen, M.J. 1896/2002a. Teine Rahva Nali. [Folk Joke 2.] http://www.folklore.ee/rl/ pubte/ee/vanad/eisen/rnali2/

Eisen, M.J. 1896/2002b. Kolmas Rahva Nali. [Folk Joke 3.] http://www.folklore.ee/ rl/pubte/ee/vanad/eisen/rnali3/

Eisen, M.J. 1897/2003. Neljas Rahva Nali. [Folk Joke 4.] http://www.folklore.ee/rl/ pubte/ee/vanad/eisen/rnali4/

Eisen, M.J. 1901/2003. Viies Rahva Nali. [Folk Joke 5.] http://www.folklore.ee/rl/ pubte/ee/vanad/eisen/rnali5/

Eisen, M.J. 1909/2003. Eesti Rahvanali. [Estonian Folk Joke.] http://www.folklore.ee/ rl/pubte/ee/vanad/eisen/ernali/sisu.html

Delfi: Delfi joke site. http://www.delfi.ee/jokes

Viikberg, Jüri 1997. Anekdoodiraamat. Naeruga eilsest. Eesti anekdoot 1960-1990. [Joke Book.] Tallinn: Eesti Keele Sihtasutus.

Online joke archive 1997- . Online joke archive of Estonian contemporary jokelore. Material from different internet joke sources collected and systematised by Liisi Laineste \& Arvo Krikmann. http://www.folklore.ee/ liisi/o2/ 